\title{
Permainan Edukasi Labirin Virtual Reality Dengan Metode Collision Detection Dan Stereoscopic
}

\author{
Sang Gde Aditya Bhaskara ${ }^{1}$, Putu Wira Buana², I Ketut Adi Purnawan ${ }^{3}$ \\ Program Studi Teknologi Informasi, Fakultas Teknik, Universitas Udayana \\ 1aditya.bhaskara95@live.com \\ 2wbhuana@it.unud.ac.id \\ 3adipurnawan@unud.ac.id
}

\begin{abstract}
Abstrak
Pengetahuan umum adalah pengetahuan yang diketahui sebagian besar masyarakat. Survei LIPI Tahun 2015 menyatakan 54\% dari 1.829 responden kurang paham terhadap informasi pengetahuan dan teknologi. Sebagian besar Masyarakat Indonesia lebih memilih menggunakan internet untuk media sosial dibandingkan mencari informasi seputar pengetahuan atau isu-isu di masyarakat [1]. Masalah ini dapat diatasi dengan media edukasi yang lebih interaktif, sehingga dapat menambah wawasan pengetahuan umum dengan cara yang menyenangkan. Virtual Reality merupakan teknologi yang mampu menciptakan lingkungan virtual yang interaktif. Virtual Reality digunakan untuk menciptakan permainan edukasi Labirin bernama LabirinVR. LabirinVR dibuat menggunakan SDK GoogleVR dengan Metode Collision Detection dan Penglihatan Stereoscopic. Interaksi permainan memanfaatkan sensor Accelerometer dan Gyroscope. Aplikasi mampu menambah kemampuan berpikir, kreativitas, serta wawasan pengetahuan umum Indonesia dan dunia. Hasil pengujian fungsi aplikasi adalah $100 \%$ valid dan penilaian aplikasi memiliki tingkat kelayakan 98\%, sehingga aplikasi memiliki nilai UAT (User Acceptence Test) [2] yang baik, serta diterima dan digunakan masyarakat.
\end{abstract}

Kata Kunci: Labirin, Virtual Reality, GoogleVR, Collision Detection, Penglihatan Stereoscopic.

\begin{abstract}
General knowledge is the knowledge most people know about. LIPI (Indonesian Institute of Sciences) Survey's in 2015 states 54\% of 1,829 respondents are less aware of knowledge and technology information. Most Indonesians prefer using internet for social media rather than seeking information about knowledge or issues in society [1]. This problem can be overcome with more interactive educational media, so can add insight of general knowledge in fun way. Virtual Reality is technology capable of creating interactive virtual environment. Virtual Reality is used to create educational game called LabirinVR. LabirinVR created using GoogleVR SDK with Collision Detection and Stereoscopic Vision Methods. Game interactions utilize Accelerometer and Gyroscope sensors. The application is able to increase the ability of thinking, creativity, and insight of general knowledge of Indonesia and the world. The application function test result is $100 \%$ valid and has $98 \%$ feasibility level, so it has good UAT (User Acceptence Test) [2], accepted and used by the people.
\end{abstract}

Keywords: Labyrinth, Virtual Reality, GoogleVR, Collision Detection, Stereoscopic Vision.

\section{Pendahuluan}

Pengetahuan umum adalah pengetahuan yang secara luas diketahui oleh sebagian besar anggota masyarakat. Pengetahuan umum bersifat ringan dan mudah diadopsi ke dalam suatu permainan. Pengetahuan umum biasanya dibatasi ruang lingkup tertentu seperti pengetahuan umum daerah, negara atau nasional, hingga dunia. Pengetahuan umum juga diklasifikasikan berdasarkan bidangnya seperti pengetahuan umum budaya, sosial, politik, tata negara, ekonomi, dan sebagainya. 
Hasil survei LIPI (Lembaga IImu Pengetahuan Indonesia) Tahun 2015 dari 10 kota di Indonesia Tahun 2015 menyatakan 54\% dari 1.829 responden kurang paham terhadap informasi pengetahuan dan teknologi. Sebagian besar masyarakat Indonesia lebih memilih menggunakan internet untuk menggunakan media sosial dibandingkan mencari informasi seputar pengetahuan atau isu-isu yang berkembang di masyarakat [1]. Permasalahan seperti ini memerlukan suatu media sebagai sarana sosialisasi atau pembelajaran pengetahuan umum bagi Masyarakat Indonesia.

Permainan (game) sebagai media pembelajaran dalam berbagai bidang ilmu pengetahuan kini berkembang sangat pesat dan telah menjadi bagian hidup bagi masyarakat. Berbagai manfaat positif dapat diperoleh, apabila permainan digunakan dan dimanfaatkan dengan baik dan benar.

Permainan Labirin merupakan permainan yang termasuk dalam kategori puzzle yang ditujukan untuk mengasah otak, kreativitas, dan pengetahuan. Permainan Labirin dapat diselesaikan dengan menemukan jalan keluar dari Labirin tersebut. Pencarian jalan keluar akan dilakukan secepat mungkin dengan menjawab beberapa pertanyaan mengenai pengetahuan umum, sehingga selama permainan secara otomatis diperlukan ingatan dan pola pikir yang baik dalam penyelesaian suatu Labirin. Permainan Labirin yang sudah ada saat ini, masih didominasi dengan antarmuka 2D. Diperlukan sebuah peningkatan teknologi antarmuka dalam permainan Labirin dengan mengubah permainan Labirin 2D menjadi permainan Labirin 3D dengan dukungan Virtual Reality. Perspektif 3D lebih baik dibandingkan perspektif 2D dalam mengintegrasikan suatu pemetaan dengan video atau citra dalam permainan [3].

The Educational Effectiveness of Simulation Games: A Synthesis of Findings yang ditulis oleh Mary Bredemeier dan Cathy Greenblat menyatakan bahwa pengalaman belajar melalui permainan simulasi menghasilkan keluaran yang lebih memuaskan bagi murid-murid [4]. Penelitian ini dilakukan dengan memperhatikan mengapa murid-murid memainkan permainan, apa yang diharapkan dan apa yang dapat dipelajari dari permainan tersebut. Hasilnya dari berbagai evaluasi, murid-murid berulang kali menyatakan bahwa pengalaman dalam memainkan permainan simulasi sangat menakjubkan, apresiasi terhadap pengetahuan meningkat dan mampu menstimulasi motivasi dan ketertarikan murid-murid tersebut. Penelitian ini membuktikan permainan simulasi menggunakan dunia virtual dapat menambah keingintahuan para murid.

J. Yap pada penelitiannya yang berjudul Virtual World Labyrinth: An Interactive Maze That Teaches Computing menyatakan bahwa permainan klasik seperti Labirin membantu pelajar untuk belajar menggunakan komputer sambil bermain menyelesaikan Labirin [5]. Penelitian ini menciptakan sebuah permainan edukasi Labirin yang dikhususkan untuk edukasi komputer. Permainan ini terbukti mampu dalam mengajarkan mengenai penggunaan komputer pada penggunanya walaupun pembelajaran dilakukan secara tidak langsung atau sambil bermain.

Shiny Mathew pada jurnalnya yang berjudul Importance of Virtual Reality in Current World, menyatakan bahwa VR sangat diperlukan karena tingginya kebutuhan manusia namun tidak disertai oleh standar penerapan solusi [6]. VR memiliki dampak nyata dalam bidang hiburan seni, bisnis, komunikasi, desain, pendidikan, teknik, kedokteran, dan bidang lainnya. Pengembangan VR saat ini juga termasuk perkembangan generasi dunia VR atau yang sering disebut MMOW (Massively Multiplayer Online World).

Penelitian yang berjudul Exploring Children's Movement Characteristics During Virtual Reality Video Game Play meneliti kuantitas dan kualitas gerakan selama bermain video game berteknologi Virtual Reality, dengan mengeksplorasi perbedaan karakteristik antara permainan dengan pengguna pemula dan pengguna berpengalaman, dan menyelidiki apakah motivasi untuk menyelesaikan permainan mempengaruhi karakteristik gerakan pengguna [7].Penelitian ini dilakukan dengan merekrut anak-anak dengan usia antara 7 hingga 12 tahun termasuk anak-anak dengan penglihatan dan pendengaran normal di usia sekolah. Pengecualian diberikan terhadap penyakit medis musculoskeletal, neurological, dan developmental. Anakanak dikategorikan berdasarkan pengalaman mereka bermain Wii dan Wii Fit. Hasil analisis yang telah dilakukan dari 38 anak-anak (22 laki-laki dan 16 perempuan) menghasilkan berbagai variasi nilai dari berbagai variabel seperti durasi bermain, perbedaan sistem permainan, kategori permainan, pengalaman bermain, dan sebagainya. Penemuan yang telah dihasilkan pada penelitian ini dapat digunakan untuk meningkatkan pemahaman klinis teknologi VR dan 
menginformasikan perkembangan pertanyaan penelitian untuk menggali potensi guna meningkatkan keterampilan gerak pada anak-anak dengan gangguan motorik.

Penelitian sebelumnya, menyatakan bahwa peran simulasi dalam suatu permainan sangat mempengaruhi karakteristik gerakan pengguna [7] dan simulasi diperlukan untuk menghasilkan keluaran yang lebih memuaskan [4]. Simulasi dapat dikombinasikan dengan suatu permainan yang mendidik. Labirin adalah permainan yang difungsikan untuk melatih kecerdasan. Labirin terbukti dapat membantu pelajar dalam belajar komputer sambil bermain menyelesaikan Labirin [5]. Simulasi lingkungan Labirin dapat dilakukan dengan teknologi yang sedang berkembang saat ini yaitu Virtual Reality. Virtual Reality adalah teknologi simulasi yang sangat diperlukan saat ini guna memenuhi tingginya kebutuhan manusia [6]. Berdasarkan permasalahan dan penelitian sebelumnya, solusi yang diberikan dalam penelitian ini adalah membuat suatu aplikasi Permainan Edukasi Labirin Virtual Reality. Permainan yang mensimulasikan lingkungan virtual Labirin yang dapat mengasah otak dan menambah wawasan pengetahuan umum, sehingga penggunaan perangkat mobile menjadi jauh lebih positif.

\section{Metodologi}

Metode penelitian yang diterapkan dalam penelitian ini adalah framework DSRM (Design Science Research Methodology). Framework ini terdiri dari beberapa tahap, yaitu studi kepustakaan, identifikasi masalah dan motivasi, penentuan tujuan penelitian, perancangan dan pengembangan solusi, demonstrasi, pengujian, pembahasan, dan kesimpulan [8].

Aplikasi ini bernama LabirinVR. LabirinVR dibuat dengan menggunakan SDK GoogleVR dengan bahasa pemrograman C\# (C-Sharp) dan Game Engine Unity. Permainan ini dijalankan pada perangkat Android yang memiliki sensor Accelerometer dan Gyroscope. Aplikasi yang dihasilkan merupakan permainan mobile yang mengkombinasikan permainan Labirin dan media edukasi dengan dukungan teknologi Virtual Reality. LabirinVR mengkombinasikan sebuah media yang mampu memberikan edukasi mengenai pengetahuan-pengetahuan umum Indonesia dan dunia yang disisipkan dalam penyelesaian permainan Labirin dengan dukungan lingkungan Labirin virtual yang disimulasikan oleh teknologi Virtual Reality.

Tabel 1 berikut merupakan spesifikasi perangkat keras yang digunakan untuk membangun dan menjalankan aplikasi LabirinVR.

Tabel 1. Kebutuhan Perangkat Keras

\begin{tabular}{cl}
\hline Kategori & \multicolumn{1}{c}{ Komponen Perangkat Keras } \\
\hline Komputer & CPU Intel Core i5-5200 Quad-core 2.20 GHz \\
& GPU Intel HD Graphic 5500 \& NVIDIA 930M 2GB DDR3 VRAM \\
& RAM 8 GB 1600 DDR3L \\
& Penyimpanan Internal 500 GB \\
Smartphone & CPU ARM Samsung Exynos Octa $54201,90 \mathrm{GHz}$ \\
& RAM 3GB \\
& Penyimpanan Internal $32 \mathrm{~GB}$ \\
& GPU ARM Mali-T628 \\
& Sensor MPU6500 Accelerometer \& Gyroscope \\
& Layar 5,7 inci (1080x1920, 386 dpi) \\
VR Viewer & VR Box BTQ007 \\
\hline
\end{tabular}

Tabel 2 berikut merupakan spesifikasi perangkat lunak yang digunakan untuk membangun dan menjalankan aplikasi LabirinVR.

Tabel 2. Kebutuhan Perangkat Lunak

\begin{tabular}{cl}
\hline Kategori & \multicolumn{1}{c}{ Komponen Perangkat Lunak } \\
\hline Komputer & Unity3D 5.3.3f1 \\
Smartphone & Android 5.0 (Lollipop) \\
Plugins & GoogleVR SDK \\
\hline
\end{tabular}

Cara kerja Permainan Edukasi LabirinVR secara umum diilustrasikan pada Gambar 1 berikut. 


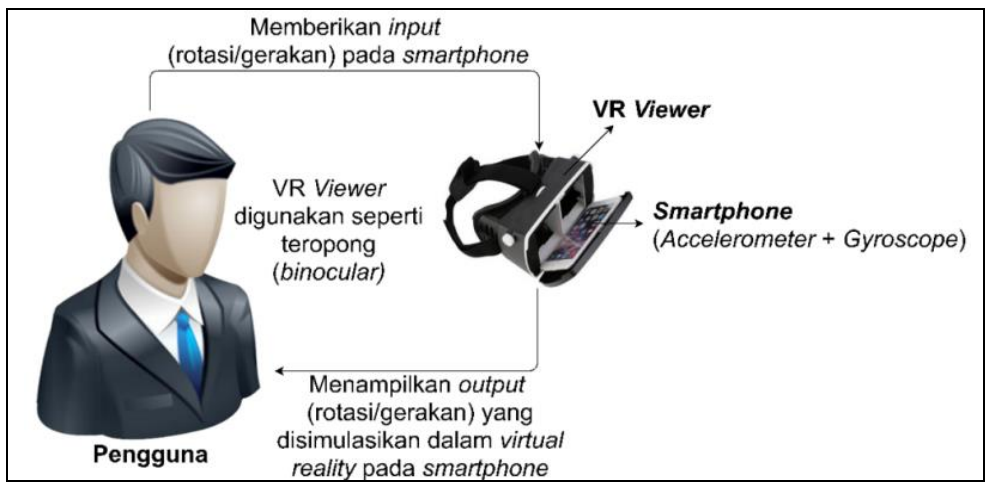

Gambar 1. Ilustrasi Cara Kerja Permainan Edukasi Labirin Virtual Reality

Berikut adalah penjelasan mendetail mengenai ilustrasi cara kerja aplikasi pada Gambar 1.

1. LabirinVR di-install dan dijalankan pada Smartphone yang memiliki sensor Accelerometer dan Gyroscope, dengan layar 5,2 sampai 6 inci agar dapat dipasang pada VR Viewer.

2. VR Viewer digunakan seperti menggunakan teropong untuk menciptakan Penglihatan Stereoscopic dan mengisolasi gangguan dari cahaya eksternal agar mata tetap terfokus.

3. Input diberikan pada Smartphone dengan rotasi/gerakan badan dan kepala. Input ini memiliki nilai sumbu $x, y$, dan $z$ yang diperoleh dari sensor dan diolah oleh Smartphone.

4. Hasil yang telah diolah disimulasikan menjadi tampilan Virtual Reality pada Smartphone.

Permainan Edukasi LabirinVR terdiri dari beberapa scene permainan yaitu scene Home, Pilih Level, Opsi, Info, Level, Level Bonus, Finish, dan Game Over. Gambar 2 menggambarkan aktivitas sistem Permainan Edukasi Labirin Virtual Reality secara umum.

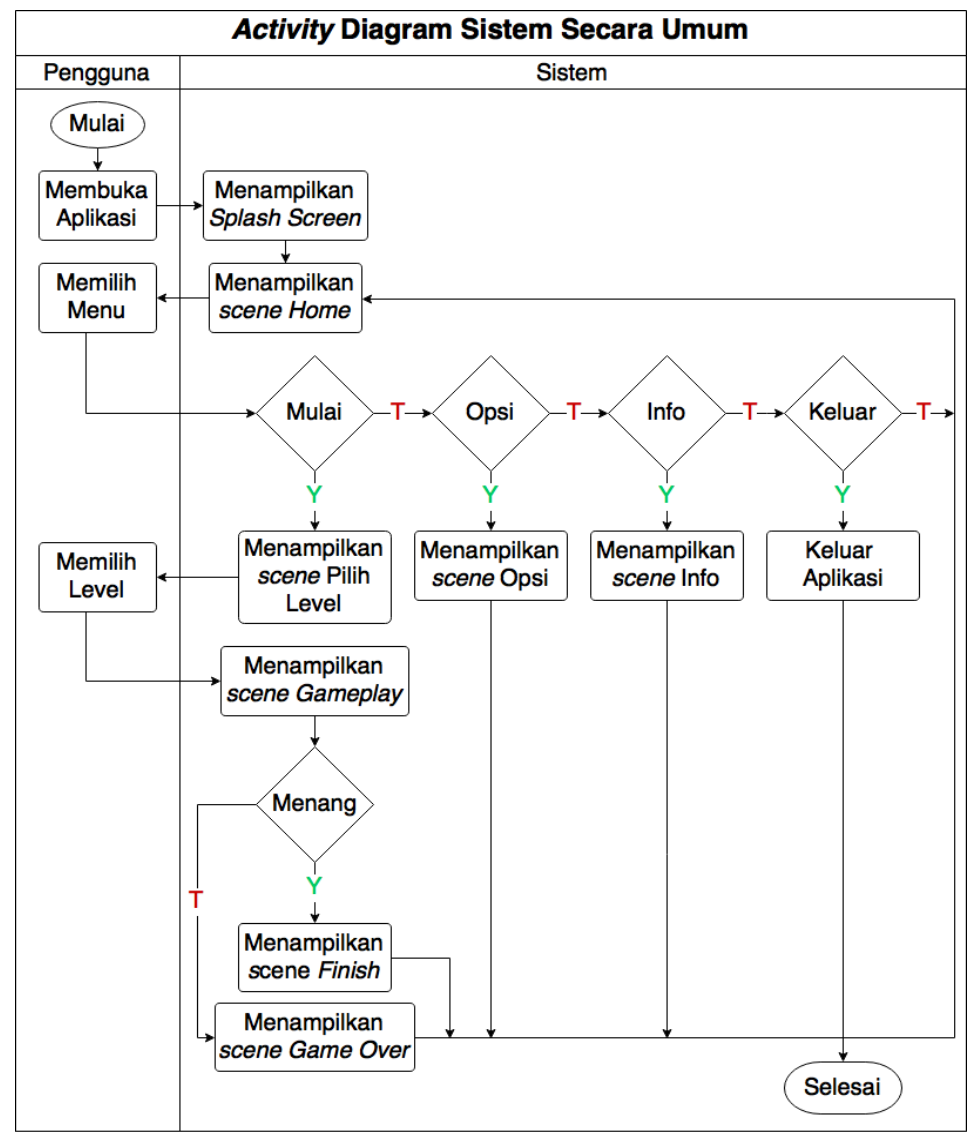

Gambar 2. Activity Diagram Aplikasi LabirinVR Secara Umum 
a. Scene Home

Scene Home adalah scene pertama yang ditampilkan ketika membuka aplikasi. Scene Home difungsikan sebagai lobi permainan. Scene ini berisi menu navigasi utama yang digunakan pada permainan LabirinVR. Menu-menu navigasi tersebut yaitu menu Mulai, Opsi, Info, dan Keluar.

b. Scene Pilih Level

Scene Pilih Level adalah scene yang akan ditampilkan ketika memilih menu Mulai. Scene Pilih Level merupakan scene yang berfungsi untuk melakukan pemilihan level permainan pada aplikasi LabirinVR. Scene Pilih Level memiliki beberapa menu navigasi level permainan.

c. Scene Opsi

Scene Opsi adalah scene yang akan ditampilkan ketika memilih menu Opsi. Scene Opsi merupakan scene yang berfungsi untuk melakukan perubahan opsi pada permainan LabirinVR. Scene Opsi memiliki beberapa opsi yang dapat diubah diantaranya musik latar, efek suara, dan kecepatan berjalan.

d. Scene Info

Scene Info adalah scene yang akan ditampilkan ketika memilih menu Info. Scene Info merupakan scene yang berfungsi untuk menampilkan informasi. Scene Info menampilkan beberapa informasi yaitu, informasi tutorial, aplikasi dan pengembang, dan credits.

e. Scene Level

Scene Level adalah scene yang akan ditampilkan ketika memilih level permainan tertentu. Scene Level merupakan scene utama permainan LabirinVR. Scene Level terdiri dari delapan level permainan. Scene Level akan menampilkan berbagai jenis pertanyaan seputar pengetahuan umum sebagai rintangan tambahan.

f. Scene Level Bonus

Scene Level Bonus adalah scene yang akan ditampilkan ketika memilih Level Bonus. Scene Level Bonus merupakan scene yang akan terbuka ketika seluruh level permainan dari Level 1 sampai Level 8 telah berhasil diselesaikan. Scene Level Bonus akan mengubah jalur labirin secara berkala sebagai rintangan tambahan.

g. Scene Finish

Scene Finish adalah scene yang ditampilkan ketika berhasil menyelesaikan suatu level permainan. Scene ini akan menampilkan tulisan "New Record?', jika berhasil mencetak rekor waktu baru, menampilkan bintang yang diperoleh berdasarkan waktu penyelesaian, serta menampilkan rekor waktu yang sebelumnya dan rekor waktu yang baru.

h. Scene Game Over

Scene Game Over adalah scene yang ditampilkan ketika tidak berhasil menyelesaikan suatu level permainan. Scene ini akan menampilkan tulisan "Game Over?".

\section{Kajian Pustaka}

\subsection{Labirin}

Labirin adalah sebuah permainan yang terbentuk dari suatu jaringan jalur-jalur yang saling berhubungan dan dibatasi oleh dinding-dinding yang memisahkan jalur yang satu dengan jalur lainnya. Jalur-jalur tersebut berliku dan terkadang merupakan jalur buntu. Labirin juga dapat didefinisikan sebagai permainan mencari jalur keluar dan kemudian bagaimana cara menemukan jalan keluarnya [9]. Pemain akan diletakkan di suatu tempat di dalam labirin. Pemain akan mencapai finish ketika berhasil menemukan jalan keluar dari sebuah labirin. Pencarian jalan keluar akan dipersulit dengan adanya jalur berliku dan rintangan yang harus diselesaikan.

\subsection{VR (Virtual Reality)}

VR (Virtual Reality) atau yang sering juga disebut VE (Virtual Environment) adalah sebuah pengembangan teknologi komputer yang mampu mensimulasikan suatu lingkungan virtual sehingga dapat berinteraksi dengan lingkungan virtual yang disimulasikan oleh komputer [10]. VR berbeda dengan AR (Augmented Reality). AR adalah teknologi yang menggabungkan benda maya ke dalam lingkungan nyata [11], sedangkan VR adalah teknologi yang 
menciptakan dunia virtual baru baik terinspirasi dari dunia nyata atau sebuah dunia hasil imajinasi. VR sepenuhnya menggantikan dunia nyata, sedangkan AR hanya menambah atau melengkapi dunia nyata [12].

\subsection{Collision Detection}

Collision Detection adalah proses untuk mendeteksi terjadinya suatu gesekan atau tabrakan antara dua objek yang bergerak dengan adanya gaya yang mempengaruhi objek tersebut. Collision Detection juga dapat didefinisikan sebagai algoritma yang digunakan untuk mendeteksi ketika sebuah objek mencoba melakukan penetrasi atau bersentuhan dengan objek yang lainnya [13]. Collision Detection merupakan masalah yang bersifat fundamental dalam robotika, animasi komputer, pemodelan objek fisik, dan simulasi environments [14]. Collision Detection dapat digunakan untuk berinteraksi dengan objek, sebagai pembatas fisik antar objek dan sebagai trigger untuk menjalankan fungsi atau program dalam permainan.

\subsection{Penglihatan Stereoscopic}

Penglihatan Stereoscopic adalah sebuah teknik untuk membuat atau menampilkan ilusi kedalaman pada sebuah citra. Penglihatan Stereoscopic juga sering disebut sebagai binocular vision. Penglihatan ini akan memvisualkan pemandangan yang sedikit berbeda yang dikhususkan untuk mata kiri dan kanan [15].

\section{Hasil dan Pembahasan}

Hasil dan pembahasan aplikasi memaparkan hasil analisa, pengujian fungsi-fungsi dan penilaian aplikasi yang telah diterapkembangkan.

\subsection{Tampilan Permainan LabirinVR}

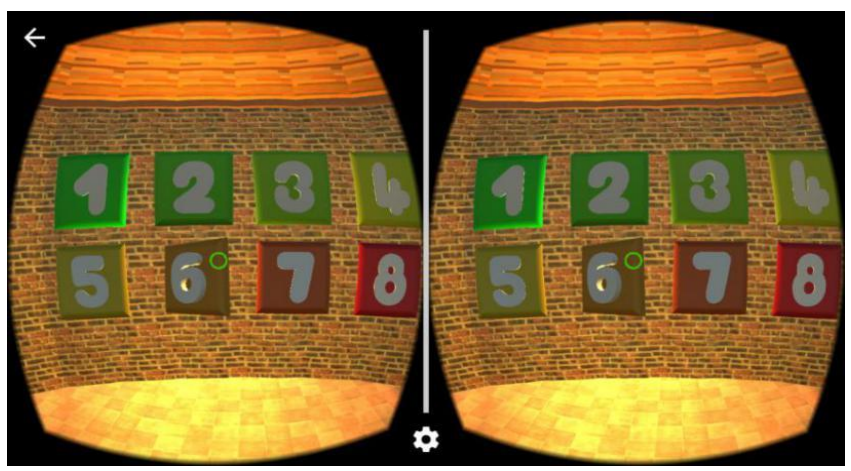

Gambar 3. Tampilan Scene Pilih Level

Gambar 3 merupakan tampilan Scene Pilih Level aplikasi LabirinVR. Scene Pilih Level berisi pilihan level permainan yang dapat dipilih yaitu dari level 1 hingga 8 yang disertai Level Bonus.

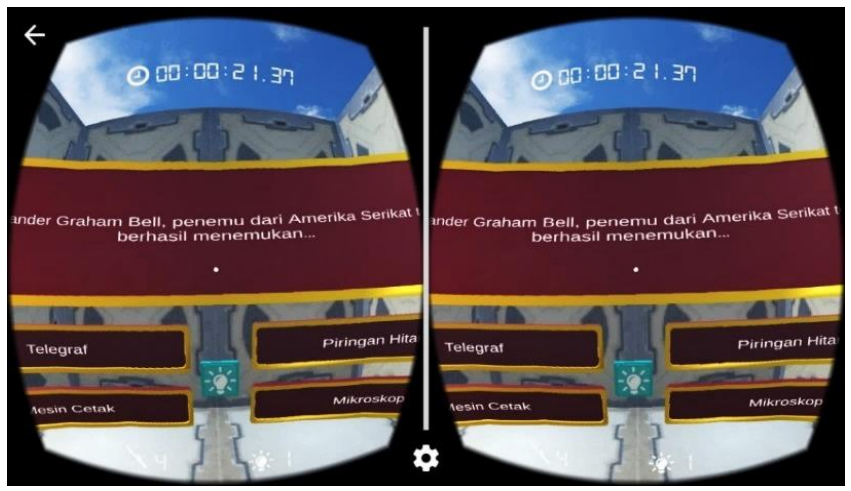

Gambar 4. Tampilan Scene Level 
Gambar 4 merupakan tampilan Scene Level aplikasi LabirinVR. Scene Level akan menampilkan berbagai jenis pertanyaan seputar pengetahuan umum sebagai rintangan tambahan, jika berhasil menjawab pertanyaan dengan benar, maka akan mendapat berbagai keuntungan seperti penunjuk arah dan tambahan waktu permainan.

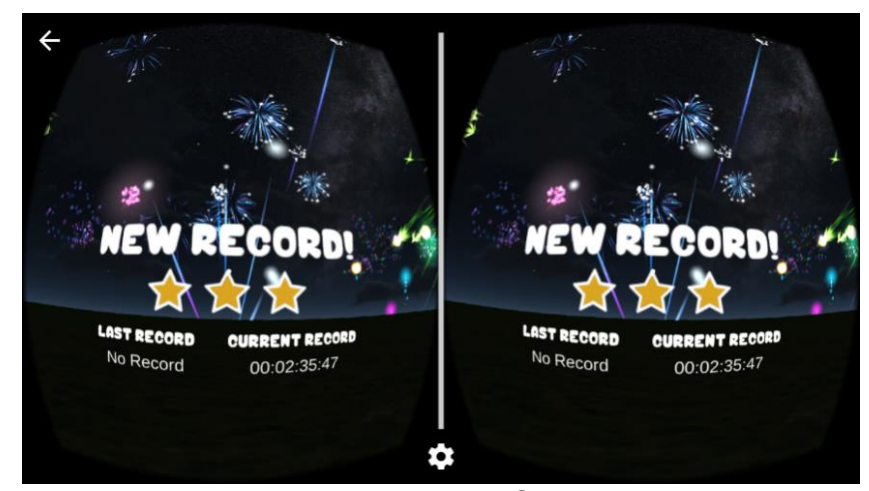

Gambar 5. Tampilan Scene Finish

Gambar 5 merupakan tampilan Scene Finish aplikasi LabirinVR. Scene Finish menampilkan tulisan "New Record!" ketika mendapat rekor yang lebih baik. Menampilkan jumlah bintang dan rekor baru setelah menyelesaikan permainan, serta rekor terakhir yang pernah didapatkan.

\subsection{Kontrol Permainan (Autowalk)}

Kontrol permainan atau fungsi Autowalk akan memanfaatkan sensor Accelerometer dan Gyroscope untuk melakukan kontrol berdasarkan sudut yang dihasilkan oleh sumbu $x$. Gambar 6 berikut merupakan diagram alir melakukan kontrol pada permainan.

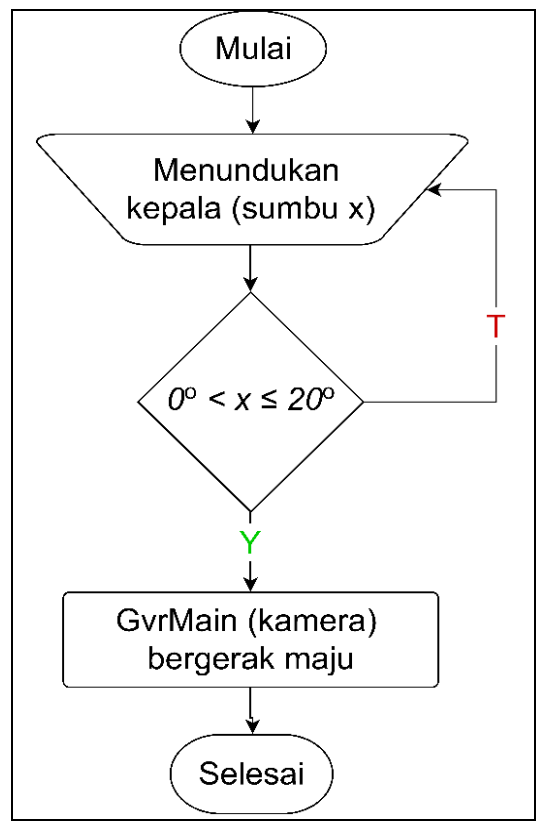

Gambar 6. Fungsi Autowalk

Berikut adalah penjelasan mendetail mengenai fungsi Autowalk pada Gambar 6.

1. Input diberikan kepada aplikasi untuk berjalan dengan cara menundukan kepala. Aplikasi memiliki rentang ukuran sudut pada sumbu $x$ yaitu lebih besar dari $0^{\circ}$ sampai $20^{\circ}$.

2. Sumbu $x$ dideteksi secara kontinu, jika nilai $x$ memenuhi kondisi $0^{\circ}<x<20^{\circ}$ maka GvrMain (kamera) bergerak maju. Semakin besar nilai $x$, maka gerak GvrMain semakin cepat. 


\subsection{Mengacak dan Menampilkan Pertanyaan}

Aplikasi mengacak dan menampilkan pertanyaan dilakukan dengan memilih pertanyaan secara acak dari basis data dan ditampilkan pada Question Panel. Gambar 7 berikut merupakan diagram alir aplikasi mengacak dan menampilkan pertanyaan.

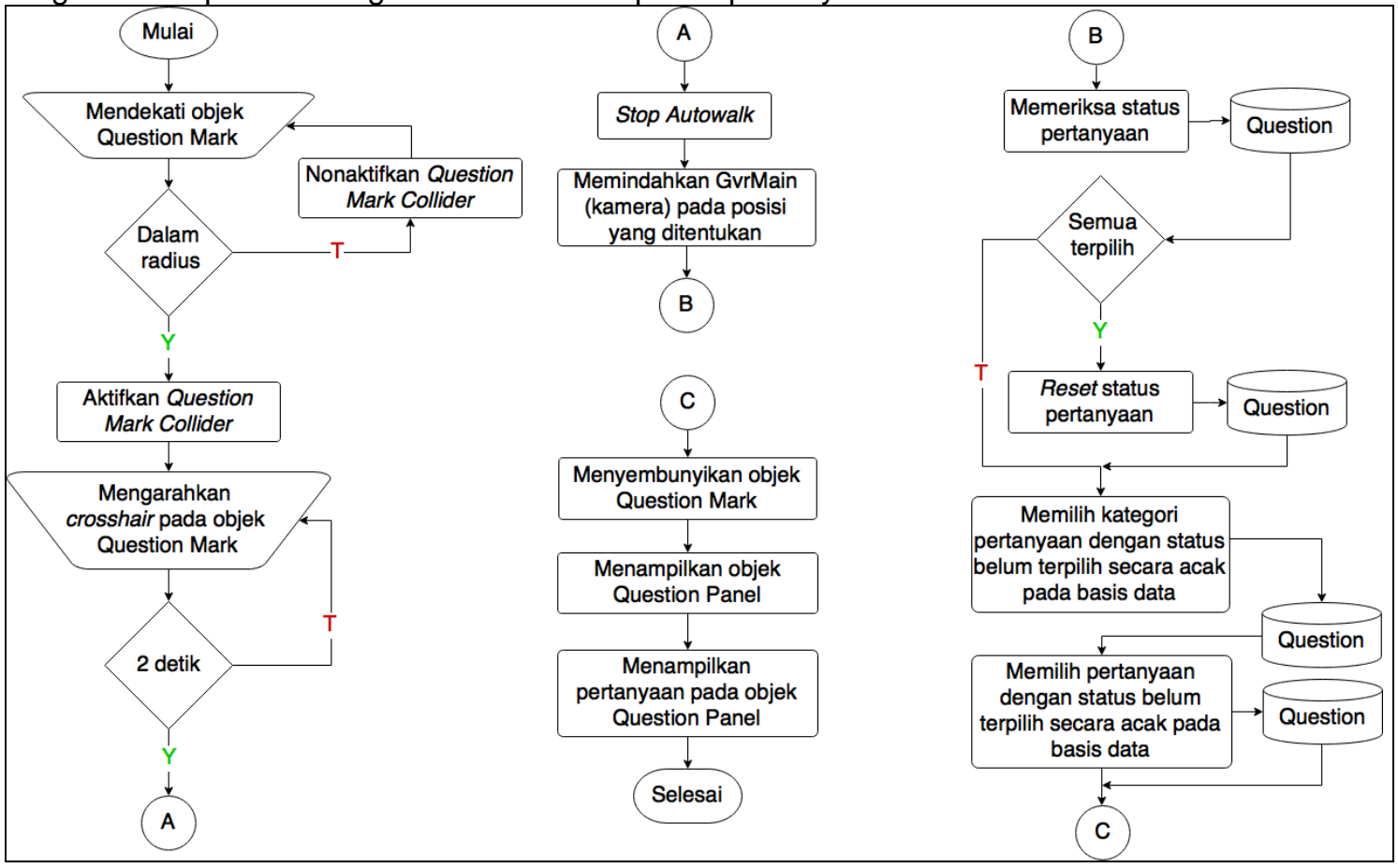

Gambar 7. Flowchart Mengacak dan Menampilkan Pertanyaan

Berikut adalah penjelasan mendetail mengenai proses Mengacak dan Menampilkan Pertanyaan pada Gambar 7.

a. Radius GvrMain (kamera) dengan Question Mark dideteksi oleh aplikasi, jika berada dalam radius tertentu dengan Question Mark maka collider yang terdapat pada Question Mark akan aktif, namun jika tidak maka collider Question Mark akan dinonaktifkan.

b. GvrMain (kamera) berada pada radius yang diperlukan dan crosshair diarahkan pada objek Question Mark.

c. Pemilihan objek Question Mark memerlukan delay time selama 2 detik untuk mengunci sasaran yang dipilih dan jika sasaran telah terkonfirmasi, fungsi Autowalk dihentikan.

d. GvrMain (kamera) dipindahkan pada posisi yang ditentukan untuk menjawab pertanyaan.

e. Aplikasi memeriksa status pertanyaan pada basis data Question, jika semua pertanyaan telah terpilih maka, aplikasi akan melakukan reset terhadap status pertanyaan.

f. Aplikasi memilih kategori pertanyaan dengan status belum terpilih dan statusnya akan di-update menjadi telah terpilih pada basis data Question.

g. Aplikasi memilih pertanyaan dengan status belum terpilih dan statusnya akan di-update menjadi telah terpilih pada basis data Question.

h. Menyembunyikan Question Mark untuk sementara dan menampilkan Question Panel.

i. Pertanyaan yang telah terpilih kemudian ditampilkan pada Question Panel.

\subsection{Basis Data Aplikasi}

Basis data pada permainan edukasi LabirinVR menggunakan RDBMS SQLite. Gambar 8 berikut merupakan skema relasi basis data SQLite yang digunakan pada aplikasi. 


\begin{tabular}{|c|c|c|c|c|c|c|c|}
\hline \multicolumn{4}{|c|}{ Question } & \multicolumn{4}{|c|}{ Level } \\
\hline & Nama Kolom & Tipe Data & Ekstra & \multicolumn{2}{|r|}{ Nama Kolom } & \multirow{2}{*}{\begin{tabular}{|l|} 
Tipe Data \\
INTEGER \\
\end{tabular}} & \multirow{2}{*}{\begin{tabular}{|l|} 
Ekstra \\
NOT_NULL
\end{tabular}} \\
\hline & Question_ID & INTEGER & NOT_NULL & PK & Level_ID & & \\
\hline & Question_Content & TEXT & NOT_NULL & \multicolumn{2}{|r|}{ Level_Name } & TEXT & NOT_NULL \\
\hline \multirow[t]{7}{*}{ FK } & Question_Category_ID & INTEGER & NOT_NULL & \multicolumn{2}{|r|}{ Level_Description } & TEXT & NOT_NULL \\
\hline & Question_Answer_A & TEXT & NOT_NULL & \multicolumn{2}{|r|}{ Level_Time1Star } & REAL & NOT_NULL \\
\hline & Question_Answer_B & TEXT & NOT_NULL & \multicolumn{2}{|r|}{ Level_Time2Star } & REAL & NOT_NULL \\
\hline & Question_Answer_C & TEXT & NOT_NULL & \multicolumn{2}{|r|}{ Level_Time3Star } & REAL & NOT_NULL \\
\hline & Question_Answer_D & TEXT & NOT_NULL & \multicolumn{2}{|r|}{ Level_Highscore_Time } & REAL & \\
\hline & Question_Answer_Right & INTEGER & NOT_NULL & \multirow{2}{*}{\multicolumn{2}{|c|}{ Level_Star }} & INTEGER & \\
\hline \multirow{2}{*}{\multicolumn{4}{|c|}{ Question_Selected }} & & & & \\
\hline & & & & \multicolumn{4}{|c|}{ Options } \\
\hline \multicolumn{4}{|c|}{ Question_Category } & \multicolumn{2}{|r|}{ Nama Kolom } & Tipe Data & Ekstra \\
\hline & Nama Kolom & Tipe Data & \begin{tabular}{l|l} 
Ea & Ekstra
\end{tabular} & \multirow[t]{2}{*}{ PK } & Options_ID & INTEGER & NOT_NULL \\
\hline & Question_Category_ID & INTEGER & \begin{tabular}{|l|l|} 
R & NOT_NULL \\
\end{tabular} & & Options_Name & TEXT & NOT_NULL \\
\hline & Question_Category_Name & TEXT & NOT_NULL & \multirow{2}{*}{\multicolumn{2}{|c|}{ Options_Value }} & \multirow[t]{2}{*}{ INTEGER } & \multirow[t]{2}{*}{ NOT_NULL } \\
\hline & Question_Category_Selected & ed INTEGER & & & & & \\
\hline
\end{tabular}

Gambar 8. Skema Relasi Basis Data SQLite LabirinVR

Gambar 8 merupakan skema yang menggambarkan basis data SQLite beserta relasinya. Basis data memiliki empat tabel yaitu,

1. Tabel Question_Category adalah tabel yang menyimpan data kategori pertanyaan. Data tersebut yaitu ID kategori pertanyaan (Question_Category_ID), judul atau nama kategori pertanyaan (Question_Category_Name), dan status kategori pertanyaan telah terpilih (Question_Category_Selected).

2. Tabel Question adalah tabel yang menyimpan data pertanyaan. Data tersebut yaitu ID pertanyaan (Question_ID), pertanyaan (Question_Content), kategori pertanyaan (Question_Category_ID) yang mengacu pada tabel Question_Category, pilihan jawaban (Question_Answer_A, Question_Answer_B, Question_Answer_C, dan Question_Answer_D), jawaban benar (Question_Answer_Right), dan status pertanyaan telah terpilih (Question_Selected).

3. Tabel Level adalah tabel yang menyimpan data detail dari setiap level Labirin. Data tersebut yaitu ID level (Level_ID), nama dari suatu level (Level_Name), deskripsi atau keterangan dari suatu level (Level_Description), ketentuan waktu untuk mendapatkan bintang (Level_Time1Star, Level_Time2Star, dan Level_Time3Star), waktu yang berhasil dicapai pada suatu level (Level_Highscore_Time), dan bintang yang berhasil diperoleh pada suatu level (Level_Star).

4. Tabel Options adalah tabel yang menyimpan data opsi permainan. Data tersebut yaitu ID opsi (Options_ID), nama dari suatu opsi permainan (Options_Name), dan nilai dari suatu opsi permainan (Options_Value).

\subsection{Kategori Pertanyaan Pengetahuan Umum}

Pertanyaan-pertanyaan yang ditampilkan dalam permainan adalah pertanyaan-pertanyaan seputar pengetahuan umum. Pertanyaan-pertanyaan ini terbagi ke dalam beberapa kategori yang dijelaskan pada Tabel 3 berikut.

Tabel 3. Kategori Pertanyaan Pengetahuan Umum

\begin{tabular}{clc}
\hline No. & \multicolumn{1}{c}{ Kategori } & $\begin{array}{c}\text { Jumlah } \\
\text { Pertanyaan }\end{array}$ \\
\hline 1 & Negara Indonesia & 6 \\
2 & Wilayah Administrasi Indonesia & 6 \\
3 & Alam Indonesia & 6 \\
4 & Iklim Indonesia & 6 \\
5 & Pembagian Daerah Waktu & 6 \\
6 & Kekayaan Alam & 6 \\
7 & Industri di Indonesia & 6 \\
8 & Waduk dan Pembangkit Listrik & 6 \\
9 & Keragaman Suku Bangsa dan Budaya & 6 \\
10 & Transportasi dan Komunikasi & 6 \\
\hline
\end{tabular}




\begin{tabular}{rlc}
11 & Sejarah dan Peninggalan Sejarah & 6 \\
12 & Perang Kemerdekaan & 6 \\
13 & Pahlawan Bangsa & 6 \\
14 & Sekolah dan Perguruan Tinggi & 6 \\
15 & Hari Nasional & 6 \\
16 & Negara Tetangga & 6 \\
17 & Pengetahuan Dunia & 6 \\
18 & PBB (Perserikatan Bangsa-Bangsa) & 6 \\
19 & Populer & 6 \\
\hline \multicolumn{2}{r}{ Total Jumlah Pertanyaan } & 114 \\
\hline
\end{tabular}

\subsection{Pengujian Fungsi-Fungsi Aplikasi LabirinVR}

Pengujian fungsi-fungsi aplikasi LabirinVR menggunakan Skala Guttman dan melibatkan 10 responden. Pengujian dilakukan untuk memvalidasi dan memastikan setiap fungsi yang terdapat pada aplikasi LabirinVR dapat berjalan dengan baik. Pengujian dilakukan pada setiap scene permainan, karena setiap scene permainan memiliki beberapa fitur yang sama atau berbeda dari scene permainan yang lainnya.

Pengujian fungsi-fungsi aplikasi LabirinVR telah dilakukan pada beberapa perangkat seperti, Samsung Galaxy Note 3, Xiaomi Note 2, Asus Zenfone 2, Sony Xperia Z2, dan Xiaomi Mi Max. Hasil dari setiap pengujian menunjukkan nilai $100 \%$, sehingga dapat disimpulkan bahwa fungsifungsi aplikasi LabirinVR telah berjalan dengan baik.

\subsection{Penilaian Aplikasi LabirinVR}

Penilaian aplikasi LabirinVR menggunakan Skala Likert dan melibatkan 70 responden. Pengujian dilakukan untuk memberikan penilaian pada berbagai aspek yaitu, Rekayasa Perangkat Lunak, Interface, Entertainment, Konten Permainan, dan Publikasi. Berikut merupakan hasil hitung penilaian aplikasi LabirinVR.

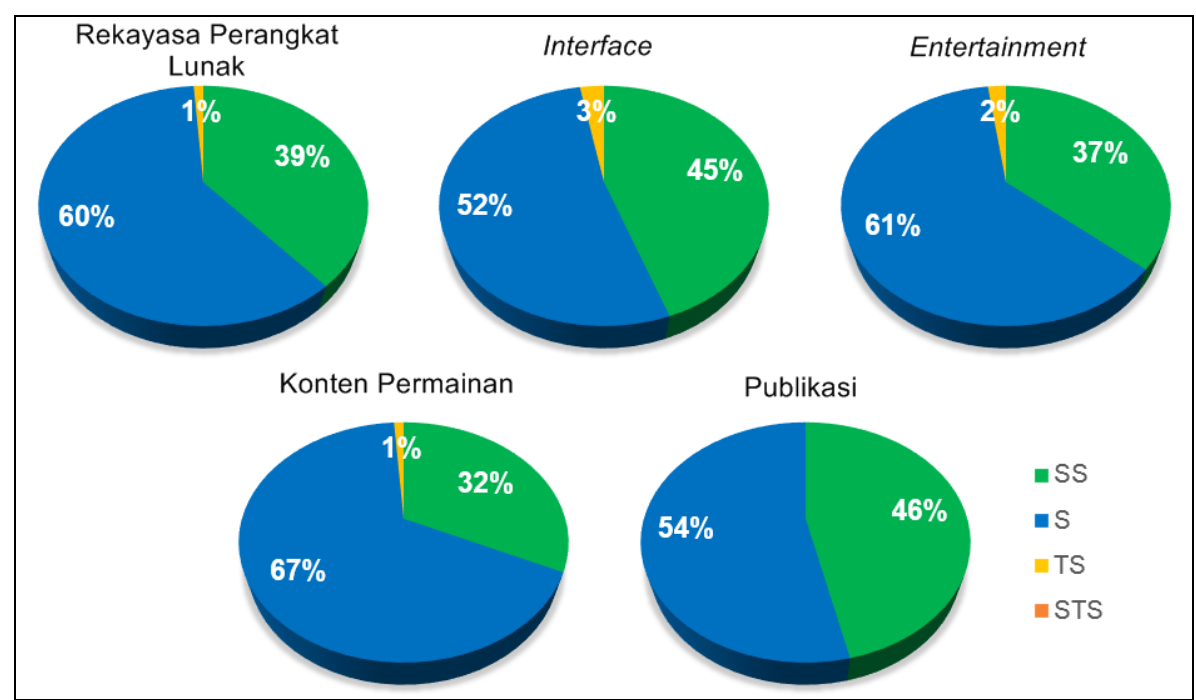

Gambar 9. Hasil Penilaian Aplikasi LabirinVR

Aspek Rekayasa Perangkat Lunak mendapatkan respon tidak setuju hanya $1 \%$, setuju $60 \%$ dan sangat setuju $39 \%$. Persentase tertinggi terdapat pada pilihan setuju, sehingga dapat disimpulkan bahwa Rekayasa Perangkat Lunak dalam permainan ini berjalan dengan baik. Persentase respon tidak setuju diperoleh karena penggunaan teknologi Virtual Reality dalam permainan. Hal ini dikarenakan teknologi Virtual Reality khususnya pada perangkat mobile merupakan teknologi baru yang belum dikenali secara luas oleh masyarakat. 
Aspek Interface mendapatkan respon tidak setuju hanya 3\%, setuju $52 \%$ dan sangat setuju $45 \%$. Persentase tertinggi terdapat pada pilihan setuju, sehingga dapat disimpulkan bahwa interface dalam permainan ini menarik. Persentase respon tidak setuju diperoleh karena aspek interface merupakan aspek dengan penilaian yang dinamis. Persepsi masing-masing responden bisa saja berbeda. Sebagian responden menyarankan agar interface aplikasi LabirinVR untuk terus ditingkatkan.

Aspek Entertainment mendapatkan respon tidak setuju hanya $2 \%$, setuju $61 \%$ dan sangat setuju $37 \%$. Persentase tertinggi terdapat pada pilihan setuju, sehingga dapat disimpulkan bahwa permainan ini adalah permainan yang menghibur. Persentase respon tidak setuju diperoleh karena genre permainan yang disukai setiap orang berbeda. Persepsi genre permainan yang disukai oleh responden berbeda-beda mulai dari permainan mudah (tidak memerlukan logika tinggi), hingga permainan yang rumit. LabirinVR merupakan permainan dengan tingkat kerumitan sedang.

Aspek Konten Permainan mendapatkan respon tidak setuju hanya $1 \%$, setuju $67 \%$ dan sangat setuju $32 \%$. Persentase tertinggi terdapat pada pilihan setuju, sehingga dapat disimpulkan bahwa Konten Permainan yang dikemas dalam permainan ini dapat dikategorikan baik. Persentase respon tidak setuju diperoleh karena permainan labirin yang sebelumnya dimainkan berbeda dengan permainan LabirinVR dengan menggunakan objek labirin 3D dan bersifat edukatif dengan memberikan tantangan berupa batasan waktu dan pertanyaan-pertanyaan seputar pengetahuan umum Indonesia dan dunia. Wawasan pengetahuan umum yang dimiliki oleh setiap responden berbeda, sehingga tidak semua pertanyaan akan dijawab dengan mudah oleh setiap responden.

Aspek Publikasi mendapatkan respon setuju $54 \%$ dan sangat setuju $46 \%$. Persentase tertinggi terdapat pada pilihan setuju, sehingga dapat disimpulkan bahwa aplikasi permainan edukasi LabirinVR dpat dan layak untuk dipublikasikan.

\section{Kesimpulan}

Permainan klasik Labirin dikombinasikan dengan media edukasi mengenai pengetahuan umum menggunakan teknologi Virtual Reality, SDK GoogleVR, dan game engine Unity3D. Model 3D didesain dan divisualisasikan dengan menggunakan Google SketchUp dengan format file .skp yang dapat di-import ke dalam game engine Unity3D. Implementasi Metode Collision Detection yaitu, menggunakan Mesh Collider, Box Collider, dan Capsule Collider untuk membatasi dan mendeteksi tabrakan antar objek. Implementasi Metode Penglihatan Stereoscopic dilakukan dengan memanfaatkan SDK GoogleVR. Interaksi di lingkungan virtual dapat dilakukan dengan memanfaatkan kombinasi sensor Accelerometer dan Gyroscope yang menghasilkan interpretasi nilai sumbu x (horizontal), y (vertikal), dan z (kedalaman), serta penerapan Metode Collision Detection pada objek dan crosshair, sehingga interaksi dapat dilakukan secara dinamis antara objek dengan objek lain dan GvrMain (kamera). Hasil keseluruhan pengujian fungsi-fungsi aplikasi dari seluruh scene permainan yaitu scene Home, Pilih Level, Opsi, Info, Level, Level Bonus, Finish dan Game Over adalah 100\% valid. Hasil keseluruhan penilaian aplikasi LabirinVR dari aspek Rekayasa Perangkat Lunak, Interface (Antarmuka), Entertainment (Hiburan), Konten Permainan, dan Publikasi memiliki tingkat kelayakan mencapai $98 \%$ yang diperoleh dari akumulasi jumlah respon setuju dan sangat setuju, sehingga aplikasi permainan edukasi LabirinVR memiliki nilai UAT (User Acceptance Test) yang baik, serta dapat diterima dan digunakan oleh masyarakat.

\section{Daftar Pustaka}

[1] http://lipi.go.id/berita/single/Survei-54-Persen-Masyarakat-Kurang-Paham-IsuIptek/11041 [diakses 28 Januari 2017]

[2] https://usersnap.com/blog/user-acceptance-testing-right/ [diakses 23 Maret 2017]

[3] C. W. Nielsen and M. a. Goodrich, "Comparing the usefulness of video and map information in navigation tasks", Proceeding 1st ACM SIGCHI/SIGART Conf. Humanrobot Interact. - HRI '06, p. 95, 2006.

[4] M. E. Bredemeier, C. S. Greenblat, "The Educational Effectiveness of Simulation Games: A Synthesis of Findings", Simulation \& Games, 12(3), pp. 307-332, 1981. 
[5] J. Yap, "Virtual World Labyrinth: An Interactive Maze That Teaches Computing", Defense Science Research Conference and Expo (DSR), 2011, 2011.

[6] S. Mathew, "Importance of Virtual Reality in Current World", International Journal of Computer Science and Mobile Computing, vol. 3, no. 3, pp. 894-899, 2014.

[7] D. Levac, M. R. Pierrynowski, M. Canestraro, L. Gurr, L. Leonard, C. Neeley, "Exploring Children's Movement Characteristics During Virtual Reality Video Game Play", Human Movement Science, vol. 29, no. 6, pp. 1023-1038, 2010.

[8] I. P. A. E. Pratama, Sistem Informasi dan Implementasinya, Bandung: Informatika Bandung, pp. 28-35, 2014.

[9] R. D. Putra, M. Aswin, D. W. Djuriatno, "Pencarian Rute Terdekat Pada Labirin Menggunakan Metode A*", EECCIS, vol. 6, no. 2, pp. 1-4, 2012.

[10] U. Asfari, B. Setiawan, A. Sani, "Pembuatan Aplikasi Tata Ruang Tiga Dimensi Gedung Serba Guna Menggunakan Teknologi Virtual Reality (Studi Kasus: Graha ITS Surabaya)", Jurnal Teknik ITS, vol. 1, no. 1, pp. A540-A544, 2012.

[11] I. D. G. W. Dhiyatmika, I. K. G. D. Putra, N. M. I. M. Mandenni, "Aplikasi Augmented Reality Magic Book Pengenalan Binatang untuk Siswa TK", Lontar Komputer: Jurnal IImiah Teknologi Informasi, vol. 6, no. 2, pp. 120-127, 2015.

[12] I. G. A. Nugraha, I. K. G. D. Putra, I. M. Sukarsa, "Rancang Bangun Aplikasi Augmented Reality Museum Bali Berbasis Android Studi Kasus Gedung Karangasem dan Gedung Tabanan", Lontar Komputer: Jurnal Ilmiah Teknologi Informasi, vol. 7, no. 2, pp. 93-103, 2016.

[13] S. Redon, A. Kheddar, and S. Coquillart, "Fast Continuous Collision Detection Between Rigid Bodies", Computer Graphics Forum, vol. 21, no. 3, pp. 279-287, 2002.

[14] M. K. Ponamgi, D. Manocha, and M. C. Lin, "Incremental Algorithms for Collision Detection Between Polygonal Models", IEEE Transactions on Visualization and Computer Graphics, vol. 3, no. 1, pp. 51-64, 1997.

[15] https://developer.mozilla.org/en-US/docs/Web/API/WebVR_API/Concepts. [diakses tanggal 25 Februari 2017] 